\title{
Erratum to: Influence of stressful fermentation conditions on neutral lipids of a Saccharomyces cerevisiae brewing strain
}

\author{
Jasminka Rupčić • Gordana Čanadi Jurešić • \\ Branka Blagović
}

Published online: 14 September 2013

(C) Springer Science+Business Media Dordrecht 2013

Erratum to: World J Microbiol Biotechnol (2010)

26:1331-1336

DOI 10.1007/s11274-009-0297-7

Unfortunately, Dr. Branka Blagović has not been added as a co-author in original publication, who has been included in this erratum.
Dr. Branka Blagović, researcher at the Department of Chemistry and Biochemistry, Faculty of Medicine at the University of Rijeka, Croatia, was inadvertently left off the manuscript as an author when it was submitted to the World Journal of Microbiology and Biotechnology. The authors Dr. Rupčić and Dr. Jurešić now wish to acknowledge Dr. Blagović as a co-author to correct this oversight.

The online version of the original article can be found under doi: 10.1007/s11274-009-0297-7.

J. Rupčić $(\varangle) \cdot$ G. Č. Jurešić · B. Blagović Department of Chemistry and Biochemistry, Faculty of Medicine, University of Rijeka, B. Branchetta 20, 51000 Rijeka, Croatia

e-mail: jasminka.rupcic@medri.hr; rjasmin@medri.hr 